\title{
Characterization of Anatolian traditional quince cultivars, based on microsatellite markers
}

\author{
C. Yüksel ${ }^{1}$, F. Mutaf ${ }^{1}$, İ. Demirtaş ${ }^{2}$, G. Öztürk ${ }^{2}$, M. Pektaşs and A. Ergüli ${ }^{1}$ \\ ${ }^{1}$ Biotechnology Institute, Ankara University, Ankara, Turkey \\ ${ }^{2}$ Ministry of Food, Agriculture and Livestock, \\ General Directorate of Agricultural Research and Policy, \\ Horticultural Research Institute, Egirdir, Isparta, Turkey \\ Corresponding author: A. Ergül \\ E-mail: ergul@agri.ankara.edu.tr
}

Genet. Mol. Res. 12 (4): 5880-5888 (2013)

Received March 12, 2013

Accepted July 17, 2013

Published November 22, 2013

DOI http://dx.doi.org/10.4238/2013.November.22.16

\begin{abstract}
We conducted simple sequence repeat (SSR) analyses of 15 traditional quince (Cydonia oblonga) cultivars from Anatolian gene sources for molecular characterization and investigation of genetic relationships. Three pear and two apple cultivars were used as references for SSR locus data analysis and to determine allele profiles between species. Eight SSR loci that were developed from apple and pear were used, and a total of 44 alleles were found among quince cultivars. The CH01F02 locus was found to have the highest identification probability, while the CH04E03 locus had the lowest identification probability. Analysis of similarity ratios between quince cultivars showed that the lowest similarity ratio was $18 \%$ (EşmeBardac1k), while the highest similarity ratio was $87 \%$ (Bursa-Osmancik and Osmancık-Viranyadevi). In the phylogenetic dendrogram, Eşme quince showed separate branching from other quince cultivars, and no synonymous accessions were found. These results suggest that SSR markers from pear and apple could be used to determine genetic
\end{abstract}


variation among quince cultivars. These findings can be used to guide future quince breeding and management studies.

Key words: Genetic diversity; SSR; Cydonia oblonga; Quince

\section{INTRODUCTION}

The genus Cydonia, known as quince (Cydonia oblonga Mill.), belongs to the family Rosaceae and the subfamily Maloideae, which includes pome fruits like apple (Malus spp) and pear (Pyrus spp). The Maloideae subfamily contains approximately 1000 species in 30 genera, all of which have 17 chromosomes (Evans and Campbell, 2002; Halász et al., 2009). Quince has been grown for over 2000 years, and its name is derived from the name of a Greek city in the town of Cydone (Sykes, 1972; Richard and Leitão, 2011). In agriculture, the quince is used mostly as a rootstock for pear cultivars and reduces maintenance and harvesting difficulties; its fruit is used in the food industry for preparing preserves, jams, jellies, and marmalades with traditional methods or modern technology. Quince is cultivated for fruit production all over the world, but most of the quince production occurs in the region where this fruit crop is supposed to have originated. The precise origin of quince is unknown, but it is thought to have originated in Northern Iran, Turkmenistan, and the far west regions of Anatolia and Greece (Sykes, 1972; Richard and Leitão, 2011).

In Turkey, quince has been cultivated for a long time, and different types and cultivars of quince are grown in different parts of Anatolia (Browicz, 1972). In 2010, Turkey was one of the most important quince producers worldwide, with production reaching 121,085 tons/year, followed by China, Uzbekistan, Morocco, Iran, Argentina, and Azerbaijan (FAO, 2012). In 1964, a germplasm collection that included different regionally developed fruit cultivars and landraces was established in Turkey (Sykes, 1972). In addition, fruit characteristics have been described for eight quince cultivars and for five other quince cultivars in Western Turkey (Sykes, 1972). Most of the economically important quince cultivars (Limon, Demir, Ekmek, and Eşme) belong to $C$. vulgaris var. pyriformis (Özbek, 1978).

The use of DNA-based molecular markers for identification and characterization of germplasm collections is a popular and reliable experimental method. The reason for this is that it is difficult to distinguish cultivars by morphological and phenological characterizations due to the influence of the environment and localities on phenotypes. In addition, quince tree and fruit morphological properties are very similar to each other, which makes distinction for reliable classifications difficult. General differentiation characteristics have been based on fruit shape, as apple shaped [C. oblonga var. maliformis (Mill)] and pear shaped [C. oblonga var. pyriformis (Dierb)] (Nagy-Déri, 2011).

The first attempt to use molecular markers for Turkish traditional quince cultivars (Şekergevrek, Ekmek, Limon, Tekeş) employed isoenzymes in 1988 (Sanchez et al., 1988). Eleven groups of quince and two groups of X pyronia (quince-pear crosses) were distinguished by isozyme patterns such as acid phosphatase, esterase, peroxidase, and phenol oxidase. As a dominant marker, random amplified polymorphic DNA (RAPD) was used (Bayazit et al., 2011) for determining genetic relationships among 13 traditional quince accessions that were selected from different parts of Turkey.

Among the DNA-based molecular markers, simple sequence repeats (SSRs) are known for being co-dominant, highly polymorphic, and having a large number of alleles per locus (Schlotterer and Tautz, 1992). SSRs have been used in pome fruit species, particularly in apple 
(Gianfranceschi et al., 1998; Liebhard et al., 2002; Galli et al., 2005; Zhang et al., 2012) and pear (Kimura et al., 2002; Yamamoto et al., 2002; Bao et al., 2007; Miranda et al., 2010; Tian et al., 2012). One more advantage of SSRs is that these markers can be easily transferred between species of the same subfamily and between closely related genera. Most cross-transferability studies have reported this for the same subfamily, especially for the Rosaceae family (Yamamoto et al., 2001; Wünsch and Hormaza 2007; Halász et al., 2009; Wünsch, 2009; Mnejja et al., 2010).

The first genetic diversity study with SSRs for quince was undertaken with 20 quince cultivars in 2004 (Yamamoto et al., 2004), and this study assumed that SSRs from pear and apple could be transferred to quince, which belongs to the same subfamily. Many researchers have used SSR and inter-simple sequence repeat (ISSR) markers to identify quince populations and clonal variation (Dumanoğlu et al., 2009; Bassil et al., 2011; Ganopoulos et al., 2011). Although pomological data have been described for some native Turkish quince accessions (Küden et al., 2009), quince genetic germplasm has not been fully identified yet, especially using SSR markers.

To assist the breeding and germplasm management of Turkish quince germplasm, the present study aimed to generate an SSR database for traditionally cultivated Turkish quince. A total of 15 quince accessions available at the National Quince Germplasm Repository at EğirdirIsparta/Turkey were analyzed for variation and genetic relationships at eight SSR loci.

\section{MATERIAL AND METHODS}

\section{Plant material}

Young leaves of 15 commercial quince cultivars were collected from the Horticultural Research Institute of Egirdir in Isparta, Turkey. In addition to these 15 accessions, two apple cultivars (Florina and Golden Delicious) and three pear accessions [Passa Cnassana, Williams, and Ankara (Büyük Malatya)] obtained from the Atatürk Central Horticultural Research Institute in Yalova, Turkey, were used as references for SSR locus data analysis and to determine allele profiles among species (Table 1).

\section{DNA isolation}

DNA was extracted from leaf tissue following Lefort et al. (1998) as described in Şelli et al. (2007). The DNA concentration was estimated spectrophotometrically (NanoDrop ND-1000) and the DNA quality was checked by $1 \%$ agarose gel electrophoresis.

\section{SSR analysis}

A total of eight SSR markers, namely CH01F02, CH01H10, CH02B12, CH01D08, and CH04E03 developed from the apple genome (Gianfranceschi et al., 1998; Liebhard et al., 2002), and KA4b, KA14, and KA16 developed from pear genome (Yamomoto et al., 2001), were used in this study. Polymerase chain reaction (PCR) amplifications were performed as described by Şelli et al. (2007). Forward primers of each pair were labeled with WellRED fluorescent dyes D2 (black), D3 (green), and D4 (blue) (Proligo, Paris, France). PCR products were diluted with sample loading solution in certain proportions according to the fluorescent dyes used in fluorescent primer labeling, followed by the addition of Genomelab DNA Size Standard Kit-400, and electrophoresed in the CEQ 8800XL capillary DNA analysis system (Beckman Coulter, Ful- 
lerton, CA, USA). Allele sizes were determined for each SSR loci using the Beckman CEQ Fragment Analysis software. In each run, two apple accessions (Golden Delicious, Florina) and three pear cultivars [Passa Cnassana, Wiliams, and Ankara (Büyük Malatya)] were included as reference cultivars in order to have consistent allele sizes over all runs, and these accessions enabled allele size comparison with other germplasms.

\section{Genetic analysis}

Identical cultivars, number of alleles, allele frequency, expected $\left(H_{\mathrm{E}}\right)$ and observed $\left(H_{\mathrm{O}}\right)$ heterozygosities, estimated frequency of null alleles $(\mathrm{r})$, and probability of identity (PI) were calculated for each loci using the IDENTITY 1.0 program (Wagner and Sefc, 1999) according to Paetkau et al. (1995). The proportion of shared alleles was calculated using ps [option 1 - (ps)] (Bowcock et al., 1994) as genetic dissimilarity in the Microsat (version 1.5) program (Minch et al., 1995). These data were then converted to a similarity matrix and a dendrogram was constructed with the unweighted pair-group method with arithmetic mean (UPGMA) (Sneath and Sokal, 1973), using the Numerical Taxonomy and Multiware Analysis System software (NTSYS-pc) (version 2.0) (Rohlf, 1988).

\section{RESULTS}

A total of eight SSR markers derived from apple and pear were used to determine the genetic diversity of 15 quince accessions, and a total of 44 polymorphic alleles were identified. The allele sizes (bp) of 20 accessions at the eight SSR loci are given in Table 1. Among the quince cultivars, the number of polymorphic alleles in each locus varied from 2 (CH04E03) to 12 (CH01F02), with an average of 5.5 (Table 2). The level of polymorphism among accessions was calculated with PI values for each of the eight SSR loci. PI values among the accessions ranged from 0.097 (CH01F02) to 0.625 (CH04E03) (Table 2). The most informative locus with regards to the PI was CH01F02 (PI = 0.097), and the least informative locus was CH04E03 (PI = 0.625).

\begin{tabular}{|c|c|c|c|c|c|c|c|c|c|c|}
\hline Species & No. & Cultivar & $\mathrm{CH} 01 \mathrm{~F} 02$ & CH01H10 & CH01D08 & $\mathrm{CH} 02 \mathrm{~B} 12$ & CH04E03 & KA14 & $\mathrm{KA} 4 \mathrm{~b}$ & KA16 \\
\hline \multirow[t]{15}{*}{ Quince } & 1 & Alaycık & $122: 138$ & $93: 95$ & $271: 271$ & $108: 120$ & $188: 200$ & 159:159 & 110:136 & $159: 159$ \\
\hline & 2 & Bardacık & $122: 132$ & $93: 95$ & $271: 271$ & $108: 120$ & $188: 200$ & $159: 159$ & $102: 132$ & $159: 175$ \\
\hline & 3 & Bencikli & $146: 184$ & 93:95 & $259: 275$ & 120:136 & 200:200 & $159: 159$ & $110: 136$ & $135: 159$ \\
\hline & 4 & Bursa & $166: 182$ & $93: 95$ & $259: 271$ & $108: 120$ & $200: 200$ & 139:149 & $110: 136$ & $135: 159$ \\
\hline & 5 & Çengelköy & $148: 182$ & 93:95 & $271: 271$ & $108: 120$ & $188: 188$ & $151: 159$ & $110: 136$ & $141: 159$ \\
\hline & 6 & Eşme & $162: 180$ & $97: 97$ & $261: 275$ & $116: 138$ & $200: 200$ & $151: 159$ & $110: 136$ & $141: 159$ \\
\hline & 7 & Havan & $122: 134$ & $93: 95$ & $271: 271$ & $108: 120$ & $188: 200$ & $151: 159$ & $102: 132$ & $147: 159$ \\
\hline & 8 & İskilip & $162: 166$ & 93:93 & $271: 271$ & $108: 128$ & $188: 188$ & 159:159 & $110: 136$ & $135: 139$ \\
\hline & 9 & İstanbul & $166: 182$ & $85: 87$ & $271: 271$ & $108: 120$ & $188: 200$ & 159:159 & 110:136 & $135: 159$ \\
\hline & 10 & Kalecik & $182: 182$ & 93:95 & $275: 275$ & $108: 120$ & $188: 200$ & $135: 159$ & $110: 136$ & $135: 139$ \\
\hline & 11 & Limon & $166: 182$ & $93: 95$ & $275: 275$ & $108: 120$ & $188: 200$ & 159:159 & $110: 136$ & $135: 159$ \\
\hline & 12 & Osmanc1k & $166: 182$ & 93:95 & $271: 271$ & $108: 120$ & $188: 200$ & 139:149 & 110:136 & $135: 159$ \\
\hline & 13 & Şekergevrek & $178: 182$ & $93: 95$ & $261: 271$ & $108: 120$ & $188: 200$ & $135: 159$ & $110: 136$ & $135: 139$ \\
\hline & 14 & Tekeş & $182: 182$ & $95: 95$ & $261: 271$ & $108: 120$ & $188: 188$ & $151: 159$ & 110:136 & $141: 159$ \\
\hline & 15 & Viranyadevi & $166: 182$ & $93: 95$ & $271: 271$ & $108: 120$ & $188: 200$ & $151: 159$ & $110: 136$ & $135: 159$ \\
\hline \multirow[t]{2}{*}{ Apple } & 16 & Golden Delicious & $168: 178$ & 93:111 & $249: 271$ & $140: 140$ & $198: 198$ & $167: 167$ & $136: 138$ & $143: 147$ \\
\hline & 17 & Florina & $182: 206$ & $93: 113$ & $253: 277$ & $126: 140$ & $196: 196$ & $167: 167$ & $136: 136$ & $143: 147$ \\
\hline \multirow[t]{3}{*}{ Pear } & 18 & Passa Cnassana & $166: 174$ & $105: 105$ & $279: 283$ & $154: 154$ & $178: 178$ & 179:187 & $80: 94$ & $117: 127$ \\
\hline & 19 & Ankara (Büyük M.) & $156: 164$ & 99:109 & $281: 295$ & $134: 134$ & $178: 178$ & $179: 185$ & $94: 94$ & $123: 133$ \\
\hline & 20 & Wiliams & $160: 174$ & $103: 103$ & $243: 279$ & $114: 134$ & $178: 204$ & $177: 185$ & $94: 94$ & $131: 135$ \\
\hline
\end{tabular}


Table 2. Number of alleles $\left(N_{\mathrm{A}}\right)$, expected heterozygosity $\left(H_{\mathrm{E}}\right)$, observed heterozygosity $\left(H_{\mathrm{O}}\right)$, probability of identity (PI), and the frequency of null alleles (r) of 15 quince cultivars analyzed at 8 SSR markers.

\begin{tabular}{lccccr}
\hline SSR loci & $N_{\mathrm{A}}$ & $H_{\mathrm{E}}$ & $H_{\mathrm{O}}$ & PI & $\mathrm{r}$ \\
\hline CH01F02 & 12 & 0.802 & 0.866 & 0.097 & -0.035 \\
CH01H10 & 5 & 0.617 & 0.800 & 0.372 & -0.112 \\
CH01D08 & 4 & 0.544 & 0.333 & 0.342 & -0.136 \\
CH02B12 & 6 & 0.620 & 1.000 & 0.366 & -0.237 \\
KA4b & 4 & 0.615 & 1.000 & 0.379 & -0.027 \\
KA14 & 5 & 0.557 & 0.600 & 0.297 & -0.137 \\
KA16 & 6 & 0.700 & 0.933 & 0.229 & -0.066 \\
CH04E03 & 2 & 0.500 & 0.600 & 0.625 & \\
Total & 44 & 4.952 & 0.132 & & \\
Average & 5.5 & 0.619 & 0.766 & & \\
\hline
\end{tabular}

The mean $H_{\mathrm{O}}$ ranged from 0.333 (CH01D08) to 1.000 (CH01F02, KA4b), with an average of 0.766 , whereas $H_{\mathrm{F}}$ ranged from 0.500 (CH04E03) to 0.802 (CH01F02), with an average value of 0.619 (Table 2). The $H_{\mathrm{O}}$ values were found to be high for $\mathrm{CH} 01 \mathrm{~F} 02$, CH01H10, $\mathrm{CH} 02 \mathrm{~B} 12$, KA4b, KA14, KA16, and CH04E03, while the $H_{\mathrm{E}}$ value was relatively high for the CH01D08 locus.

The frequency of one or more alleles in each SSR locus were found to be higher than that of other alleles at the same loci: allele 182 in CH01F02 (0.3000), allele 93 in CH01H10 (0.3750), allele 275 in CH01d08 (0.1500), alleles 108 and 120 in CH02B12 (0.3250), allele 159 in KA14 (0.4750), allele 136 in KA4b (0.400), allele 159 in KA16 (0.3250), and alleles 188 and 200 in CH04E03 (0.3750) (Table 3). As for differences in allele size (bp) among reference cultivars and quince cultivars, comparison of apple and quince cultivars found no common allele size in CH02B12, CH04E03, and KA14, whereas comparison of pear and quince cultivars showed no common allele in CH02B12, CH04E03, CH01D08, CH01H10, KA14, and KA4b loci (Table 1 and Table 3). The frequency of null alleles at CH01D08 ( $\mathrm{r}=0.136)$ loci was positive (Table 2), but these low values showed the absence of null alleles.

Table 3. Allele frequencies of 8 SSR loci of quinces and reference apple and pear cultivars.

\begin{tabular}{cccccccccccccccccc}
\hline N & CH01f02 & Freq. & CH01h10 & Freq. & CH01d08 & Freq. & CH02b12 & Freq. & KA14 & Freq. & KA4b & Freq. & KA16 & Freq. CH04e03 & Freq. \\
\hline 1 & 122 & 0.0750 & 85 & 0.0250 & $243^{*}$ & 0.0250 & 108 & 0.3250 & 135 & 0.0500 & $80^{*}$ & 0.0250 & $117^{*}$ & 0.0250 & 178 & 0.1250 \\
2 & 132 & 0.0250 & 87 & 0.0250 & $249^{*}$ & 0.0250 & $114^{*}$ & 0.0250 & 139 & 0.0500 & $94^{*}$ & 0.1250 & $123^{*}$ & 0.0250 & 188 & 0.3750 \\
3 & 134 & 0.0250 & 93 & 0.3750 & $253^{*}$ & 0.0250 & 116 & 0.0250 & 149 & 0.0500 & 102 & 0.0500 & $127^{*}$ & 0.0250 & $196^{*}$ & 0.0500 \\
4 & 138 & 0.0250 & 95 & 0.3250 & 259 & 0.0500 & 120 & 0.3250 & 151 & 0.1250 & 110 & 0.3250 & $131^{*}$ & 0.0250 & $198^{*}$ & 0.0500 \\
5 & 146 & 0.0250 & 97 & 0.0500 & 261 & 0.0750 & $126^{*}$ & 0.0250 & 159 & 0.4750 & 132 & 0.0500 & $133^{*}$ & 0.0250 & 200 & 0.3750 \\
6 & 148 & 0.0250 & $99^{*}$ & 0.0250 & 271 & 0.0500 & 128 & 0.0250 & $167^{*}$ & 0.1000 & 136 & 0.4000 & 135 & 0.2500 & $204^{*}$ & 0.0250 \\
7 & $156 *$ & 0.0250 & $103^{*}$ & 0.0500 & 275 & 0.1500 & 134 & 0.0750 & $177^{*}$ & 0.0250 & 138 & 0.0250 & 139 & 0.0750 & - & - \\
8 & $160^{*}$ & 0.0250 & $105^{*}$ & 0.0500 & $277^{*}$ & 0.0250 & 136 & 0.0250 & $179 *$ & 0.0500 & - & - & 141 & 0.0750 & - & - \\
9 & 162 & 0.0500 & $109^{*}$ & 0.0250 & $279^{*}$ & 0.0500 & 138 & 0.0250 & $185^{*}$ & 0.0500 & - & - & $143^{*} 0.0500$ & - & - \\
10 & $164 *$ & 0.0250 & $111^{*}$ & 0.0250 & $281^{*}$ & 0.0250 & $140^{*}$ & 0.0750 & $187 *$ & 0.0250 & - & - & 147 & 0.0750 & - & - \\
11 & 166 & 0.1750 & $113^{*}$ & 0.0250 & $283^{*}$ & 0.0250 & $154^{*}$ & 0.0500 & - & - & - & - & 159 & 0.3250 & - & - \\
12 & $168^{*}$ & 0.0250 & - & - & $295^{*}$ & 0.0250 & - & - & - & - & - & - & 175 & 0.0250 & - & - \\
13 & $174 *$ & 0.0500 & - & - & - & - & - & - & - & - & - & - & - & - & - & - \\
14 & 178 & 0.0500 & - & - & - & - & - & - & - & - & - & - & - & - & - & - \\
15 & 180 & 0.0250 & - & - & - & - & - & - & - & - & - & - & - & - & - & - \\
16 & 182 & 0.3000 & - & - & - & - & - & - & - & - & - & - & - & - & - & - \\
17 & 182 & 0.0250 & - & - & - & - & - & - & - & - & - & - & - & - & - & - \\
18 & $206 *$ & 0.0250 & - & - & - & - & - & - & - & - & - & - & - & - & - & - \\
\hline
\end{tabular}

Freq. $=$ allele frequency. ${ }^{*}$ Alleles were not found among quince genotypes. 
Analysis of genetic similarity indices between quince cultivars showed that the lowest similarity was $18 \%$ (Eşme-Bardacık), while the highest similarity was approximately $87 \%$ (Bursa-Osmanc1k and Osmancık-Virandevi) (Table 4). In the dendrogram, reference cultivars and quince cultivars grouped in three main branches. Among the quince cultivars, Eşme showed significant distinction, being grouped in a different branch than the other quince cultivars (Figure 1). No synonymous accessions were found among the quince cultivars.

Table 4. Genetic similarities (\%) between quince cultivars.

\begin{tabular}{|c|c|c|c|c|c|c|c|c|c|c|c|c|c|c|c|}
\hline $\begin{array}{l}\text { Quince } \\
\text { cultivar }\end{array}$ & Alaycık & Bardacık & Bencikli & Bursa & Çengelköy & Eşme & Havan & İskilip & İstanbul & Kalecik & Limon & Osmancık & Şekergevrek & Tekeş & Viranyadevi \\
\hline Alaycık & 1 & & & & & & & & & & & & & & \\
\hline Bardacık & 0.750 & 1 & & & & & & & & & & & & & \\
\hline Bencikli & 0.562 & 0.438 & 1 & & & & & & & & & & & & \\
\hline Bursa & 0.562 & 0.438 & 0.625 & 1 & & & & & & & & & & & \\
\hline Çengelköy & 0.688 & 0.562 & 0.438 & 0.562 & 1 & & & & & & & & & & \\
\hline Eşme & 0.312 & 0.188 & 0.438 & 0.312 & 0.375 & 1 & & & & & & & & & \\
\hline Havan & 0.688 & 0.812 & 0.375 & 0.438 & 0.625 & 0.250 & 1 & & & & & & & & \\
\hline İskilip & 0.562 & 0.438 & 0.375 & 0.438 & 0.562 & 0.250 & 0.375 & 1 & & & & & & & \\
\hline İstanbul & 0.688 & 0.562 & 0.500 & 0.625 & 0.625 & 0.312 & 0.500 & 0.625 & 1 & & & & & & \\
\hline Kalecik & 0.562 & 0.438 & 0.562 & 0.562 & 0.562 & 0.312 & 0.438 & 0.500 & 0.562 & 1 & & & & & \\
\hline Limon & 0.688 & 0.562 & 0.688 & 0.688 & 0.625 & 0.375 & 0.500 & 0.562 & 0.750 & 0.812 & 1 & & & & \\
\hline Osmancık & 0.688 & 0.562 & 0.500 & 0.875 & 0.688 & 0.250 & 0.562 & 0.562 & 0.750 & 0.625 & 0.750 & 1 & & & \\
\hline Şekergevrek & 0.625 & 0.500 & 0.500 & 0.625 & 0.625 & 0.312 & 0.500 & 0.562 & 0.625 & 0.812 & 0.688 & 0.688 & 1 & & \\
\hline Tekeş & 0.562 & 0.438 & 0.375 & 0.500 & 0.812 & 0.438 & 0.500 & 0.438 & 0.562 & 0.562 & 0.562 & 0.562 & 0.625 & 1 & \\
\hline Viranyadevi & i 0.750 & 0.625 & 0.562 & 0.750 & 0.812 & 0.375 & 0.688 & 0.625 & 0.812 & 0.688 & 0.812 & 0.875 & 0.750 & 0.688 & 1 \\
\hline
\end{tabular}

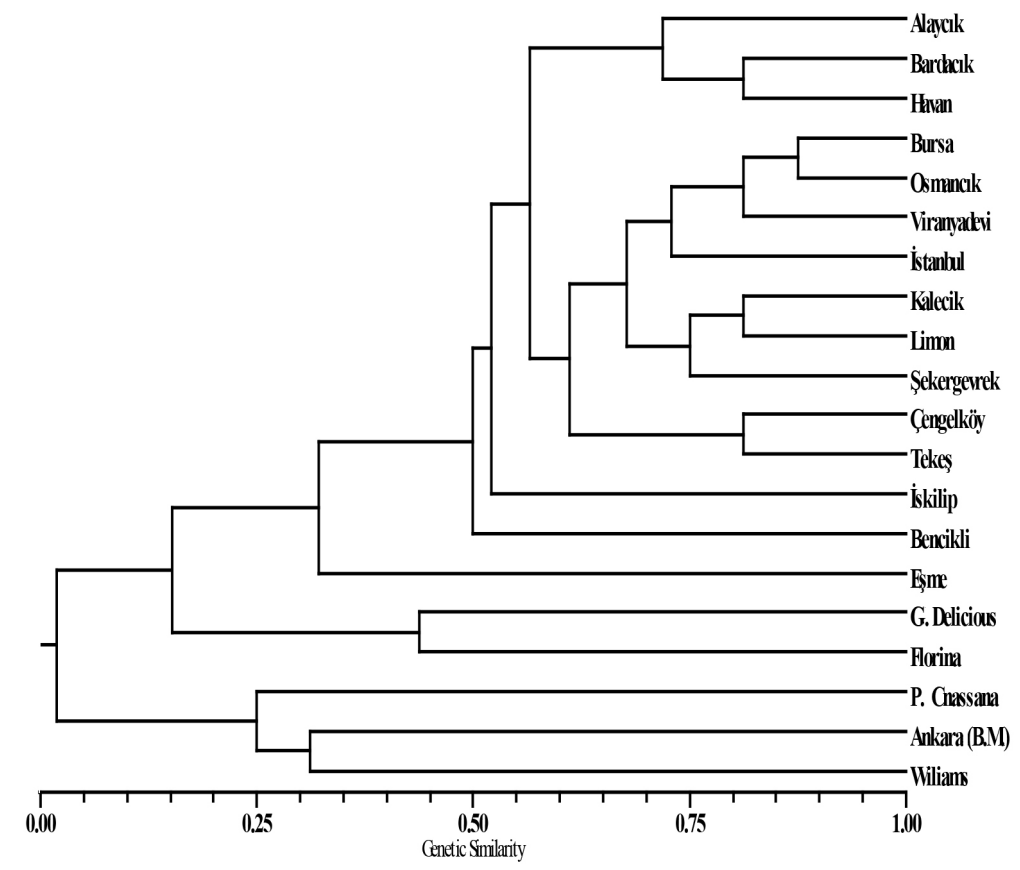

Figure 1. UPGMA cluster analysis of the SSR data from quince and reference pear and apple cultivars based on Jaccard's coefficient of genetic similarity. 


\section{DISCUSSION}

SSR markers developed from other Prunus species (apple and pear) were used successfully for the genetic characterization of quince cultivars in this study, as has been observed previously (Dumanoğlu et al., 2009; Halász et al., 2009; Bassil et al., 2011).

In a study carried out by Halász et al. (2009) for the characterization of 36 quince cultivars using seven SSR loci developed from apple, it was reported that the loci CH04E03 and CH01F02 gave lower allele numbers when compared to other SSR studies (Liebhard et al., 2002; Galli et al., 2005) conducted on apple cultivars. In the present study, although the CH04E03 locus also gave the lowest number of alleles, the CH01F02 locus was surprisingly found to produce the highest number of alleles of all loci. In addition, in a study (Bassil et al., 2011) to identify 91 quince cultivars from different countries along with Turkish cultivars such as Ekmek, Limon, Şekergevrek, and Tekeş with SSR markers, polymorphism degrees determined in CH01F02, CH01D08, and CH01H10 loci were found to be low. However, in our study, among the 15 quince cultivars, these loci gave 12, 4, and 5 alleles, respectively, and showed a significant level of polymorphism.

Yamamoto et al. (2004) reported that SSR loci originating from apple and pear could be used in genetic distinction and identification studies for quince; however, they also reported that KA4b, KA14, and KA16 loci from pear could not be used for identification, as they showed more than two bands. In our study, these loci showed adequate polymorphism and played an active role in identification and distinction of the 15 quince cultivars analyzed.

In addition, Dumanoğlu et al. (2009) found that in addition to CH01F02, CH01H10, $\mathrm{CH} 02 \mathrm{~B} 12$, and $\mathrm{CH} 01 \mathrm{D} 08$, the loci KA14 and KA16 showed a clear distinction in clones analyzed, and clonal differences emerged, indicating that these loci are indeed effective in quince cultivar identification.

Due to the lack of any common allele between species, three loci (CH02B12, CH04E03, and KA14) and six loci (CH02B12, CH04E03, CH01D08, CH01H10, KA14, and $\mathrm{KA} 4 \mathrm{~b}$ ) can preferably be used for comparisons of pear-quince and apple-quince cultivars, respectively.

In our study, the $H_{\mathrm{O}}$ values were found to be high for $\mathrm{CH} 01 \mathrm{~F} 02, \mathrm{CH} 01 \mathrm{H} 10, \mathrm{CH} 02 \mathrm{~B} 12$, $\mathrm{KA} 4 \mathrm{~b}$, KA16, and CH04E03 loci (Table 2), and previous reports also found relatively high $H_{\mathrm{O}}$ values for CH01F02, CH02B12, and KA16 (Dumanoğlu et al., 2009) and for CH01H10 (Dumanoğlu et al., 2009; Bassil et al., 2011) in some quince cultivars.

Similarity ratios between 'Limon-Kalecik' and 'Limon-İstanbul' cultivars that were based on RAPD markers used in a previous study (Bayazit et al., 2011) were similar with those obtained in the present study. The similarity ratio between Kalecik-Osmancik was found to be the same $(62 \%)$ in both studies. Similarity ratios between Çengelköy-Limon and Çengelköyİstanbul cultivars were not equivalent between studies; however, and there was instead a $20 \%$ difference. The fact that we observed no synonymous cultivars among quince species, and that genetic similarity ratios between 15 local quince species were very high indicate the richness of quince gene sources in Anatolia.

Although germplasms of fruit species (grape, plum, apricot, etc.) from Turkey have been genetically characterized with SSR markers and other molecular markers (Ayanoğlu et al., 2007; Akpınar et al., 2010; Bayazit et al., 2011; Yilmaz et al., 2011), no SSR-based genetic identification study has been conducted on Turkish quince germplasm without clonal variation study of Kalecik quince cultivar by Dumanoğlu et al. (2009). The findings of this study will 
help to identify Turkey's quince germplasm, and will assist in the improvement of agricultural practices, such as quince propagation, quince breeding, and promote better management strategies for quince cultivars.

\section{REFERENCES}

Akpınar AE, Kocal H, Ergul A, Kazan K, et al. (2010). SSR-based molecular analysis of economically important Turkish apricot cultivars. Genet. Mol. Res. 9: 324-332.

Ayanoğlu H, Bayazit S, İnan G, Bakir M, et al. (2007). AFLP analysis of genetic diversity in Turkish green plum accessions (Prunus cerasifera L.) adapted to the Mediterranean region. Sci. Hortic. 114: 263-267.

Bao L, Chen K, Zhang D, Cao Y, et al. (2007). Genetic diversity and similarity of pear (Pyrus L.) cultivars native to East Asia revealed by SSR (simple sequence repeat) markers. Genet. Resour. Crop Evol. 54: 959-971.

Bassil NV, Postman JD, Hummer KE, Mota J, et al. (2011). Quince (Cydonia oblonga) genetic relationships determined using microsatellite markers. Acta Hortic. 909: 75-84.

Bayazit S, Imrak B, Küden A and Kemal Güngör M (2011). RAPD analysis of genetic relatedness among selected quince (Cydonia oblonga Mill.) accessions from different parts of Turkey. Hort. Sci. 38: 134-141.

Bowcock AM, Ruiz-Linares A, Tomfohrde J, Minch E, et al. (1994). High resolution of human evolutionary trees with polymorphic microsatellites. Nature 368: 455-457.

Browicz K (1972). Cydonia Miller. In: Flora of Turkey and the East Aegean Islands (Davis PH, ed.). Edinburgh University Press, Edinburgh, 157.

Dumanoğlu H, Gunes NT, Aygun A, San B, et al. (2009). Analysis of clonal variations in cultivated quince (Cydonia oblonga "Kalecik") based on fruit characteristics and SSR markers. N. Z. J. Crop Horticult. Sci. 37: 113-120.

Evans RC and Campbell CS (2002). The origin of the apple subfamily (Maloideae; Rosaceae) is clarified by DNA sequence data from duplicated GBSSI genes. Am. J. Bot. 89: 1478-1484.

FAO (Food and Agricultural Organization) (2012). Avaiable at [http:॥www.faostat.fao.org]. Accessed January 2012.

Galli Z, Halász G, Kiss E, Heszky L, et al. (2005). Molecular identification of commercial apple cultivars with microsatellite markers. Hort. Sci. 40: 1974-1977.

Ganopoulos I, Merkouropoulos G, Pantazis S, Tsipouridis C, et al. (2011). Assessing molecular and morpho-agronomical diversity and identification of ISSR markers associated with fruit traits in quince (Cydonia oblonga). Genet. Mol. Res. 10: 2729-2746.

Gianfranceschi L, Seglias N, Tarchini R, Komjanc M, et al. (1998). Simple sequence repeats for the genetic analysis of apple. Theor. Appl. Genet. 96: 1069-1076.

Halász J, Hoffmann V, Szabó Z, Nyéki J, et al. (2009). Characterization of quince (Cydonia oblonga Mill.) cultivars using SSR markers developed for apple. Inter. J. Hort. Sci. 15: 7-10.

Kimura T, Shi YZ, Shoda M, Kotobuki K, et al. (2002). Identification of Asian pear varieties by SSR analysis. Breed. Sci. 52: $115-121$.

Küden A, Tümer MA, Güngör MK and İmrak B (2009). Pomological traits of some selected quince types. Acta Hort. 818: 73.

Lefort F, Lally M, Thompson D and Douglas GC (1998). Morphological traits, microsatellite fingerprinting and genetic relatedness of a stand of elite oaks (Q. robur L.) at Tullynally, Ireland. Silvae Genet. 473: 5-6.

Liebhard R, Gianfranceschi L, Koller B, Ryder CD, et al. (2002). Development and characterisation of 140 new microsatellites in apple (Malus $\mathrm{x}$ domestica Borkh.). Mol. Breed. 10: 217-241.

Minch E, Ruiz-Linares A, Goldstein DB, Feldman MW, et al (1995). Microsat (Version 1.4d): A Computer Program for Calculating Various Statistics on Microsatellite Allele Data. University of Stanford, Stanford.

Miranda C, Urrestarazu J, Santesteban LG and Royo JB (2010). Genetic diversity and structure in a collection of ancient Spanish pear cultivars assessed by microsatellite markers. J. Am. Soc. Hort. Sci. 135: 428-437.

Mnejja M, Garcia-Mas J, Audergon JM and Arús P (2010). Prunus microsatellite transportability across rosaceous crops. Tree Genet. Genomes 6: 689-700.

Nagy-Déri H (2011). Morphological investigations on anthers and pollen grains of some quince cultivars. Acta Biol. Szeged. 55: 231-235.

Özbek S (1978). Special Pomology. Çukurova University Faculty of Agriculture Press, 128: 488.

Paetkau D, Calvert W, Stirling I and Strobeck C (1995). Microsatellite analysis of population structure in Canadian polar bears. Mol. Ecol. 4: 347-354.

Richard LB and Leitão JM (2011). Wild Crop Relatives: Genomic and Breeding Resources, Temperate Fruits. Springer- 
Verlag Berlin Heidelberg, Berlin.

Rohlf F (1988). NTSYS-PC Numerical Taxonomy and Multivariate Analysis System. Version 2.0. Exeter Publishing Ltd., Setoukat.

Sanchez EE, Menedez RA, Daley LS, Boone RB, et al. (1988). Characterization of quince (Cydonia) cultivars using polyacrylamide gel electrophoresis. J. Environ. Hort. 6: 53-59.

Schlotterer C and Tautz D (1992). Slippage synthesis of simple sequence DNA. Nucleic Acids Res. 20: 211-215.

Şelli F, Bakır M, İnan G, Aygün H, et al. (2007). Simple sequence repeat-based assessment of genetic diversity in "Dimrit" and "Gemre" grapevine accessions from Turkey. Vitis 46: 182-187.

Sneath PHA and Sokal RR (1973). Numerical Taxanomy. Freeman, San Francisco.

Sykes JT (1972). A description of some quince cultivars from western Turkey. Economic Bot. 26: 21-31.

Tian L, Gao Y, Cao Y, Liu F, et al. (2012). Identification of Chinese white pear cultivars using SSR markers. Genet. Resour. Crop. Evol. 59: 317-326.

Wagner HW and Sefc KM (1999). Identity 1.0. Centre for Applied Genetics. University of Agricultural Science, Vienna.

Wünsch A (2009). Cross-transferable polymorphic SSR loci in Prunus species. Sci. Hortic. 120: 348-352.

Wünsch A and Hormaza JI (2007). Characterization of variability and genetic similarity of European pear using microsatellite loci developed in apple. Sci. Hortic. 113: 37-43.

Yamamoto T, Kimura T, Sawamura Y, Kotobuki K, et al. (2001). SSRs isolated from apple can identify polymorphism and genetic diversity in pear. Theor. Appl. Genet. 102: 865-870.

Yamamoto T, Kimura T, Sawamura Y, Manabe T, et al. (2002). Simple sequence repeats for genetic analysis in pear. Euphytica 124: 129-137.

Yamamoto T, Kimura T, Soejima J, Sanada T, et al. (2004). Identification of quince varieties using SSR markers developed from pear and apple. Breed. Sci. 54: 239-244.

Yilmaz B, Bakir M, Çelikkol BP, Kazan K, et al. (2011). Genetic characterization of grape (Vitis vinifera L.) germplasm from Southeast Anatolia by SSR markers. Vitis 50: 99-106.

Zhang Q, Li J, Zhao Y, Korban SS, et al. (2012). Evaluation of genetic diversity in chinese wild apple species along with apple cultivars using SSR markers. Plant Mol. Biol. Rep. 30: 539-546. 